\title{
Understanding the role of ULRs in developing distinctive approaches to union learning
}

\section{Steve Shelley}

Centre for Research in Employment Studies,

University of Hertfordshire Business School

College Lane

Hatfield

Hertfordshire

AL10 9AB

UK

Tel: 00441707285421

Email: s.m.shelley@herts.ac.uk 


\title{
Understanding the role of ULRs in developing distinctive approaches to union learning
}

\begin{abstract}
This article aims to provide a broad understanding of the role of ULRs and the contribution of union education and learning initiatives. It examines the scope for union learning to be distinctive and sustainable and it does this by summarising and building upon an holistic review of research of ULR activity across the range of work and unions in the UK. It finds that there are opportunities arising from union learning, particularly for individuals to access learning opportunities for the first time, enabling economic and social well-being; and the potential to develop critical awareness, reflection and action, with an emphasis on learning through social participation. It also stresses the need for caution in assessing achievement to date, with research suggesting a narrow focus of union learning, on increasing supply of qualifications rather than raising skill demand, and on low-level qualifications with little added value. It concludes that ULRs can play a central role in strengthening the contributions of learning initiatives through the union movement.
\end{abstract}




\section{Understanding the role of ULRs in developing distinctive approaches to union learning}

\section{Introduction}

This is an important time in the development of trade unions' roles in learning activities and in employment relations more widely. The last few years in the UK have seen new opportunities for unions to become involved in education, training and particularly 'learning' activities as part of the government's learning and skills policy. At the same time, trade unions have had to cope with a declining membership and reduced influence, which has led to a keen interest in a variety of strategies for union renewal.

Union Learning Representatives (ULRs) undertake a key role in the delivery of trade unions' and the government's learning strategy. ULRs are deemed to add value to employers' efforts to develop their workforce; help overcome employee resistance to learning; provide advice to 'hard-to-reach' workers and those who may be unwilling to approach their employer/manager about training; ensure the training provided meets workers' skills needs; and provide an impetus to training in organisations where there is no training manager (DfEE, 2001; CIPD, 2004). Although initiated in a voluntary way from 1998, much greater impetus was given to the ULR role with the statutory rights to recognition and paid time off to undertake ULR duties provided by the 2002 Employment Relations Act. So much so, that 15,000 ULRs had been appointed by 2007 (a figure targeted to rise to 22,000 by 2010) and had contributed to over 100,000 workers being encouraged into learning (Rees, 2007).

This article provides an understanding of the role of ULRs in the context of contemporary and historical union education and learning initiatives, and employment 
relations perspectives, by summarising and building upon an holistic review of research into trade union learning first brought together in an edited volume in 2007 (Shelley and Calveley, 2007). This summary is of ULR and related activity across the range of work and unions in the UK and readers of this journal should bear this in mind when comparing their particular sector and profession-specific experiences to this overview.

In making this assessment, it is important to understand the term 'learning' as a relatively recent phenomenon now in use in government and union policy circles, although the terms 'education' and 'training' have been synonymous with trade union activity for more than a century in the UK (Calveley, 2007a) and are similarly long-lived in other countries. Historically, the class based and collective nature of union education was something distinctively for and owned by the trade union movement. On the former, education was seen as a way for individual workers to obtain economic advancement and a share of the profits of capitalism. On the latter, workers' education was intended to bring about societal change. In addition to these education activities, trade unions run their own training programmes for activists (Spencer, 2002; Stirling, 2005), developing their workplace representatives with the necessary skills for effective workplace bargaining and representation and also including knowledge of contemporary workplace 'issues' and of union context, labour history, economics and politics. A third area of trade union involvement has been in workplace vocational education and training, although union power to undertake such activities dwindled during the 1980s and 1990s, as institutional structures were disbanded and traditional occupations closed down (Rainbird, 2000). 
Most recently, in the last decade trade unions in the UK have been increasingly involved in an agenda of 'learning', the terminology of which appears to be replacing or at least supplementing that of 'education' and 'training'. This is particularly following the election of the 'new' Labour government in 1997. Current policy context is witnessed in government documents 'The Learning Age' (DfEE, 1998), incorporating a vision of 'lifelong learning' in a 'learning society', this being reinforced further with the establishment of the Learning and Skills Council in 2001 resulting from the Learning and Skills Act (2000) and, most recently, the Leitch Review of Skills in 2006 (Leitch, 2006). As the Leitch Review makes clear, the UK has skills shortcomings, including a large proportion of the workforce unskilled and low skilled, does not compare well with other countries in terms of productivity, and has social problems of disadvantage and relative poverty. In this set of policies all 'learning' is deemed inherently 'good' to the benefit of all, individuals, economy and society, enabling economic growth and greater social inclusion and advantage.

In this context unions have increasingly re-established their involvement in this policy arena. In 1998 the government established the Union Learning Fund (ULF), funding the development of Union Learning Representatives (ULRs), union-run learning centres and other union learning initiatives in the workplace. Although this, to some extent, may be viewed as an attempt by New Labour to mollify the trade unions (they had already announced that they were not going to reverse the restrictive trade union policies introduced by their Conservative predecessors), an explicit rationale for this has been empirical correlations between training incidence and union recognition and the access to hard-to-reach learners that trade unions are thought to have (TUC, 2002; CIPD, 2004; 
Stuart and Robinson, 2007). Thus there is now a substantial amount of public funding for learning channeled through trade unions alongside the reinforced trade union rights to paid time-off for union learning activities given to ULRs under the 2002 Employment Relations Act. In line with these policy moves, trade unions and the TUC have established their own organisations as support to the government's learning and skills agenda. To support ULRs and their role in the workplace, the TUC Learning Services was established in 1998 to train ULRs and provide them with advice on moving the training agenda forward. The TUC's Unionlearn, originally set up as the Union Academy in 2005 and renamed in 2006, is now responsible for both the traditional education and the emerging learning activities (Rees, 2007), exemplifing the use of 'learning' as the over-arching terminology for the field of activity.

Given this context it is necessary to assess this more recent union involvement in 'learning' particularly by comparing the nature of 'traditional' trade union 'education' activities with the more recent field of 'learning'. Education may be seen as central to trade unions' organising agendas and at the heart of political and ideological stances. It also has a history of delivery that is often distinctive to the union movement. It is thus insightful to consider the extent to which these characteristics shape the broader contemporary union learning agenda too, thus enabling a greater understanding of the ways in which trade union learning is distinctive from learning provided by other organisations. This distinctiveness may be through sources of funding, determination of curriculum, the learners themselves and through the collective and worker-based nature of the learning delivery and the dynamics involved in pedagogy; also defined by the 
sustainability of unions' learning provision in terms, for example, of funding sources and organisation.

This article examines the scope for such a distinctiveness and aims to develop understanding of the ULRs' role in this. Three inter-related issues are considered. Firstly, the nature of union learning itself, its variety of forms and purposes, and the outcomes for individuals involved in learning activities. Secondly, the role of union learning in public policy and political economy of skill; in overcoming disadvantage in qualifications and access to training; in linking to national competitiveness and economic growth; and the learning and skills policies of government and agencies. Thirdly, examination of the relationship between the learning and union renewal agendas and the role that learning plays for trade unions and the trade union movement as a whole.

\section{The form and purpose of union learning}

Successive research reports have highlighted evidence of skills deficits in the UK (Keep and Mayhew, 1999; Lloyd and Payne, 2002), culminating in the Leitch Review of Skills (Leitch, 2006). As Lloyd and Payne (2002 and 2007) establish, the causes of this are rooted in the distinctive political economy and wider institutional structures of the UK, with a prevalence of low skilled work outweighing employer demand for high skills. From government and other mainstream viewpoints, policy resolution for skill problems has been focused on increasing the supply of trained and qualified labour, rather than on employers' demand creating a greater proportion of high skilled jobs (Lloyd and Payne, 2007). From a traditional employment relations perspective this throws into sharp perspective the different interests of capital and labour, as employers seek to control 
labour and limit costs through restrictions on the acquisition and use of skill in the labour process, in the context of their broader product and service market strategies. Trade union education has therefore aimed to provide a radical education, with an explicit agenda of societal transformation; enabling individuals to progress economically by obtaining a greater share of the profits of capitalism; and to transform the individual, which may lead to evolutionary, incremental societal change.

The tension between oppositional conflict stance and accommodative compromise, pervasive throughout trade union activities (Salaman, 2000; Stirling, 2005), has often been a visible undercurrent to the education of workers and training of members as activists and representatives for a century or more of union activity (Calveley, 2007a). In union education and training today there are probably elements of individual and societal transformation as well as economic progress for individuals through the ability to support members' employment rights and claims (Rees, 2007). In many respects the UK may be seen to be leading the way in terms of trade union involvement in a 'learning' agenda that embraces a wide spectrum of liberal humanist, vocational and basic skills training for adult and youth workers, setting an example of union involvement in this field in comparison to other countries (Calveley, 2007b). Nevertheless, an examination of the unions' recent heightened role in UK government learning and skills policy, through the Union Learning Fund (ULF), Union Learning Representatives (ULRs) and Unionlearn (Rees, 2007), and also other tripartite bodies such as the Learning and Skills Council, indicates both a continuation of the traditional union agendas in education, and a continuation of the accommodative-conflict tensions, albeit with some new operational activities (Shelley and Calveley, 2007). 
The more recent learning agenda provides opportunities for unions to obtain funding and to gain a legitimacy through accreditation of learning that comes from being part of government-initiated qualification and assessment structures. Accreditation can include both vocational and professional qualifications and range from Entry Level to Level 4 or higher, although the majority of union learning tends to be vocational and at lower levels (Shelley, 2007a; Wray, 2007). Nevertheless, there is potential for union learning initiatives and ULRs within them to play a part in regeneration activities at individual, regional and national levels. Indeed, as advocates for skills development at workplace level, ULRs have had notable successes in widening and developing individuals' access to learning opportunities that enable people to change their lives. In turn, these efforts aim to contribute to the development of a high skills economy in the UK.

There are ample illustrations of advantageous outcomes for learners, including enhanced access to learning opportunities, concomitant equality advantages, and an emphasis on improving basic skills. Low grade and low or unqualified staff have often been a focus of union learning activity (McBride and Mustchin, 2007), whilst Wray's (2007) case studies of union learning initiatives for 'hard to reach' learners, illustrate hugely positive outcomes in terms of practical abilities, confidence and social contact. The affective outcomes of increased confidence and empowerment of learners are very strong recurring themes (Forrester, 2007; Kirton, 2007; Shelley, 2007a). At the same time, skill acquisition also extends beyond current roles to include assistance in career progression and for higher qualified workers. These efforts are on the one hand intent on providing learning for learning's sake, and on the other hand undoubtedly continue the 
unions' traditional agenda of enabling enhanced economic (wage) outcomes for members through their improved ability to perform in jobs. Shelley and Calveley (2007) also conclude that there are illustrations of an extension of motive from an economic to a broader family, community and social agenda, in line with government rhetoric, reexpressed most recently in the Leitch Review (2006), to improve societal inclusivity and egalitarianism by learning initiatives reducing deprivation and poverty.

Trade union education and training has traditionally been characterised by a distinctiveness derived from a pedagogy of collective learning and of active learning methods that enable learners to set their own agenda within a broad curriculum. As Forrester (2007) identifies, there is potential for union learning to follow a similar pedagogical line. Acknowledgment of activity theory (Forrester, 2007), in which individuals and groups learn to survive and develop through societally and culturallyembedded learning activities; and a recognition of the contribution that learning can make to collective strategies for social change (Kirton, 2007), can all lead to a more positive assessment of the potential for union learning to enable incremental transformation for learners and society. Indeed, Shelley (2007a) and Kirton (2007) show some evidence that the distinctiveness of union education is being retained and extended into the learning field, with potential to enable an incremental role of agency in social change. Further, Lloyd and Payne (2007) demonstrate potential for unions to develop an independent learning agenda at policy and workplace levels, which will influence skill levels independent of employers' strategies and possibly also influence employer demand for higher skills. 


\section{The role of union learning in public policy}

However, despite the advances and optimism expressed above, evidence of the impact of union learning is currently limited. This is especially so when seeking to establish the impact on employers' skill strategies. The majority of analysis suggests that policy, practice and research in union learning has tended to default to one of an assumed unitarist neo liberal and human capital paradigm, within a current voluntarist and marketbased training and skills environment (Forrester, 2007; Lloyd and Payne, 2007; Shelley, 2007b). In becoming supporters of the government's skills strategy and making a contribution within this framework, unions are currently struggling to avoid dependence upon state funding, qualification, curriculum and quality assurance structures, so threatening their ability to have an independent and critical voice within skills policy. As a result, it can be suggested that current union learning has a relatively narrow focus, on increasing supply of qualifications rather than skill demand, and on low level qualifications with little value added (Forrester, 2007; Shelley and Calveley, 2007).

With the recent Leitch Review recommending public funding only for training that is 'economically valuable' and delivered within government and employer institutional structures of Learning and Skills Council, Sector Skills Councils and through approved, quality-assured government programmes such as Learner Accounts (Leitch, 2006), further warning signals should be sounding for those interested in developing a broader and more fundamental impact for union learning. In this respect, Holmes (2004) asserts that the current cult of 'learnerism' is oppressive in its conformance to normative behaviours and reproduction of identities and social practices. Various others (for example, Ainley, 1999; Grugulis, 2003) have warned of the dangers of qualification 
structures limiting the range of learning. Such critiques parallel those of Freire and Althusser (Taylor 1993) who assert that the state's control of education is about maintaining the conditions for production through 'know-how' education and submission to rules. The consumerist and market based context of mainstream learning and skills policy within which union learning is embedded (Ainley, 1999), places an emphasis on consumption of individualised qualification attainment which can be, as Freire (1972) posits, characterised by the need to have rather than to be, and by being materialistic, with qualification-based conformance in a job, salary and promotion structure, the measure of this. Such individualised performativity is replicated by employers in their work organsations; Forrester (2007) suggesting that unions are involved now in union learning because of a recognition by some organisations and human resource management practitioners of the commercial benefits of harnessing workers' knowledge.

Consideration therefore needs to be given to understanding how greater independence and power may enable union involvement in a wider range of learning deemed 'useful' in the extent to which it may bring about changes to low pay and low skill labour market structures, and enable learners to change their positions in society. A key issue is the extent to which unions perpetuate and conform with the status quo, as oppressors themselves complicit in mainstream learning agendas, and the extent to which they enable worker freedom (Shelley and Calveley, 2007).

In seeking to understand the influence that unions can bring to effect change in learning and education, trade unions' power and influence on delivery through their new institutional position may be seen as relatively limited, falling short of social partnership models that exist in some other European countries (Calveley, 2007b; Stirling, 2007). 
This is partly due to the limited extent of trade union recognition agreements due to the continued absence of this in government legislation, although the demand for a legal right to bargain on training has been central to the policy of the Trades Union Congress (TUC) for many years (TUC 2005). In this respect, the UK has much to learn from other countries which have more deeply enshrined corporatist approaches to union involvement in workplace training bargaining (Calveley, 2007b).

Shelley and Calveley (2007) also question whether unions would be strong enough to push employers to make meaningful improvements in training, whether statutory bargaining rights exist or not. By way of an example, even in a sector such as the National Health Service where unions are working from a position of strength relative to other sectors of employment, where membership is relatively high, where there has been a history of involvement in collective bargaining and where training spend has been a strength; McBride and Mustchin (2007) argue that unions' roles are limited and compromised. On the one hand, unions have been able to use their traditional bargaining role to extend firstly to involvement in career and pay progression schemes, and thus to a learning agenda that includes both current role and future career development. However, McBride and Mustchin (2007) summarise that the partnership approaches to involvement are not without cost to trade union independence, unions having 'bought in' to the managerial agenda of labour cost control, performance management and labour substitution, provision of narrow vocational skills on the employer's agenda and skills development that is predominantly limited to workers' current roles. A further illustration of the lack of trade union power is seen in Wray's (2007) example of the failed English for Speakers of Other Languages (ESOL) programme, showing all too starkly the 
dependence on employers' willingness to be involved as a stakeholder in learning projects, and how the success of projects is jeopardised by employers' prioritisation of production needs over learning and their constraints of low pay work environments.

For those involved in union learning, and for ULRs in particular, an awareness of these limitations and problems is key if union learning is to deliver a new and distinctive set of outcomes. Shelley and Calveley (2007) identify that a major challenge for unions concerns their ability to engage government and employers in measures aimed at raising the demand for and utilisation of skill in the workplace. They also question unions' ability to leverage a distinctive learning contribution, but on the latter suggest that some of the answers could come from drawing on the strengths of traditional practices in union education and training, and extending those more explicitly to the union learning agenda. The equality and diversity agendas are a strong strand through union campaigning generally, and through union education; as is the skilling of workers regardless of employer or culture; union involvement in the English language training for migrant workers is a good example of this.

Further, rather than focus on individual qualification and accreditation, and on individual economic gains, 'traditional' trade union 'education' has been made distinctive through delivery by adherence to a collective union-based approach, resulting in a rich experience of discussion that sets topics within the real experiences of workers and within political, social and economic spectrums (Rees, 2007). In this respect, Stirling (2007) shows how pedagogies between tutor and trainee that are two-way not only enable representatives and activists to deliver union policy consistently, but also enable the kinds of discussions that lead to emergence of new directions for union activity. Developing an 
understanding of how this aspect of distinctiveness in delivery can be reinforced in the 'learning' as well as the 'education' activities would be necessary. However, strengthening delivery through a pedagogy of student and tutor-led discussion, enabling as Elsey (1986) suggests the incorporation of critical analysis as well as continuing to build self confidence and commitment to action, operating in physical environments that are controlled by union and workers, and emphasising broader educational provision in learning aims, may all be important elements.

There are also questions over the financial sustainability of union 'learning' activities, with Shelley and Calveley (2007) illustrating problems associated with funding constraint, uncertainty and short-term, time limited funding patterns and dependency on government sources; together with the political risk that may come through a change of government or key ministers. In contrast to union learning, funding for union education is largely derived internally within the union movement, ultimately through membership subscription and other donations. This may not be the answer for the full range of union learning because, as Stirling (2007) acknowledges, this source is under pressure due to falling membership. Nevertheless it does provide an alternative consideration in the context of what seems to be an urgent need for the union movement to develop alternative funding streams that may, in some way, be called 'their own', to gain if not independence then at least diversification of funding.

It is therefore apparent that unions will need to consider how to diversify funding sources away from limited qualification-based public funding and from employersubsidised learning centres; and to develop community-based work with other local learning forum, community agencies and voluntary organisations. Both Wray (2007) and 
Shelley (2007b) illustrate the ability of unions to shape learning projects outside of the workplace and the potential to gain alternative funding from such ventures.

In summarising this section, it is apparent that unions will need to further develop an independent and sustainable set of learning initiatives, building on practices from the more traditional and long-lived education and training sector of union activity. However, such solutions are largely focused on learning delivery and on the supply side of the skills equation. If unions are to make a different and significant contribution, this should also be judged on the extent to which employers' working practices and business strategies are amended and the extent to which government policy can be influenced in this respect. The ability of unions to influence the learning agenda in these more fundamental ways will be dependent on their power, relative to employers and government. The current approach of the union movement towards learning, must be understood in the context of the role and strategies of trade unions in contemporary employment relations. It is here that the synergy between union learning and union organising is apparent, and this is where this article now turns its attention.

\section{Union learning, organisation and renewal}

In summarising the contributions in their volume, Shelley and Calveley (2007) conclude that, despite the more conciliatory approach of the Labour government since 1997, trade union influence in the UK remains limited by their relatively weak institutional place, within the current neo-liberalist government approach. Such weaknesses are also apparent in other countries, as Calveley (2007b) identifies declining membership and some weakening of trade union power within employment relations 
structures, even where union roles are enshrined in over-arching tripartite structures, in comparator countries. Nevertheless, trade union strength differs from country to country, and is still relatively strong where institutional structures have historically involved trade unions in decision-making. On the training issue specifically, the incorporation of training in workplace or sector bargaining in some countries provides an important organising vehicle for unions; albeit the reality of unions' abilities to organise varies considerably according to such factors as sector of employment and size of firm.

Strategically unions have choices to make about the approaches they can take towards organising through the learning agenda. These can be seen in the context of broader strategies for renewal and resilience (Stirling, 2005). Such strategies can be passive, reactive and accommodative, as 'business unionism', within which partnership approaches typify contemporary policy (Salaman, 2000). In another strategic view, members can be seen as consumers with unions in a servicing role (Salaman, 2000). Other strategies may be based on a re-assertion of the importance of activism and organising of a more oppositional or militant nature. On the latter, 'mobilisation theory' Kelly (1998) asserts that militancy rather than moderation is more likely to win concessions from employers and ensure union survival by appealing to members.

In terms of learning, the servicing approach can be seen through the way in which unions provide a training and qualification service to members who are consumers; an approach which can be interpreted as a membership recruitment and retention strategy. The partnership and accommodative approaches are exemplified at policy level by inclusion in public funding schemes (the Union Learning Fund) and by involvement in institutions such as the Learning and Skills Council. Indeed, it would seem that there are 
potential gains from what may be called 'buy in' to the mainstream learning and skills delivery, including awareness of union existence, contribution and leverage (of funds, facilities), economic and social gains; which in turn may recruit more members and activists. It can be argued that such stances for unions to take more benign or servicing approaches can expand the union role into what may be seen as the less adversarial learning agenda, one that enables possibility of unions cooperating with management around learning, and one which is less threatening and confrontational and that will therefore appeal to new members and activists other than traditional shop stewards (Healey and Engel, 2003).

However, the evidence of substantial developments in membership and activism remains inconclusive. A survey by the Working Lives Research Institute found that 78 per cent of ULRs had previously been active in the union movement and that few ULRs were new union members. However, it also found that women, younger activists and those from black ethnic minorities were more likely to be amongst the small proportion of ULRs who were new activists. It also supported earlier research, suggesting that the learning agenda has a positive increase on union membership generally (Moore and Wood, 2005). Nevertheless, Stuart and Wallis (2007) find no real indication that, in generating new membership enthusiasm, this had impacted significantly on the strengthening of branch organisation. At best, this may be a rather long term endeavour for trade unions.

Stuart and Wallis (2007) attribute the causes of these organising problems partly to the role of workplace learning bargaining arrangements being a single issue, often dealt with informally through an 'integrative' mutual interest employment relations structure, 
as an issue of 'partnership', and separate from the more traditional distributive bargaining structures for pay, terms and conditions. However, whilst this may aid the recruit of new activists who prefer to avoid confrontation, this is at risk of losing trade union independence and of delivering employers' training for them which could also turn members and activists off. In addition, the separateness of the learning agenda has meant that learning issues are taken less seriously by other shop stewards and members in local union branches, and that those working in the learning field may be sidelined and isolated from the wider union activity and support. In going for a predominantly partnership approach on the learning agenda, there is a risk that the very subject of learning itself is marginalised, and a risk that the value of unions' involvement in the activity is negated.

As a way to bolster union organisation, Shelley and Calveley (2007) note that Kelly's (1998) mobilisation theory has been largely ignored in the mainstream strategies towards union learning. As previously noted, Kelly (1998) posited that a more traditional conflict approach brings influence and credibility. Following this interpretation, on the one hand activists may prefer not to see hard distributive bargaining machinery (for example, on pay and conditions) diluted by softer integrative arrangements on learning. In contrast, Kirton (2007) demonstrates the power of union education to strengthen activist roles within trade unions, an important aspect of union organisation and renewal that is derived from a central role in mainstream union activity, preparation for and location in a traditional distributive bargaining purpose. The situation is also complex as Stuart and Wallis (2007) demonstrate, even if learning and distributive bargaining arrangements are ostensibly separate, they will influence each other. In this respect Stuart 
and Wallis (2007) cite the example of a recent strike on the traditional area of pay which was thought to have strengthened the union's ability to be able to bargain on learning.

In summary, a critique would suggest that partnership approaches to learning may jeopardise development of a distinctive approach to trade union learning (Sutherland and Rainbird 2000); and that there is merit in seeking further gains in the learning and organising agendas through more confrontational approaches. If unions are to gain strength in order to influence the uses of learning and learning policy, development of membership and organisation is key. Mobilisation theory (Kelly, 1998) suggests that union learning that is independent, distinctive and sustainable and which is seen to have a significant and direct impact on working conditions will be attractive to new members and activists; and that, in turn, such improved organisation and power should allow greater leverage on bargaining over learning provision and skills levels at workplace and national levels. It is therefore clear that there are key considerations for union policy in terms of the benefits or otherwise of integrating learning into the traditional distributive adversarial machinery, although such strategic considerations will need a balance of approaches.

\section{Conclusion}

In conclusion, it appears that the opportunities arising from union learning are immense. There is potential for contemporary union learning to embody the spirit of the union movement and of union learning, education and training over the last hundred years or more, but also make new contributions in the current context. Shelley and 
Calveley (2007) suggest that there is much to welcome, echoing recent reports published by Unionlearn (Moore and Wood, 2007; Thompson et al, 2007).

Further, there is a distinctiveness in union learning that can be attained from the dynamics involved in pedagogy, the purpose, the learners and the social context of worker-based learning delivery. By the very nature of its context, no learning is benign and uncontested. Taylor (1993) asserts that there is no such thing as a neutral education process, a view that is recognised by Forrester (2007), Rees (2007) and Shelley (2007a). The situated contextual nature of learning, in collective organizations and communities of practice, in which there is social participation and development of knowledge of self about and with others, and an understanding of workplace and union learning within wider societal relationships, arguably do contribute to a differentiated nature of union learning, albeit as considered earlier, one that may need to open up greater opportunity for learners to develop critical awareness, reflection and action. In this way, union learning can be independent of other learning and training activities in the education and training arena, financially and in terms of determination of curriculum and of learning attainments, and in terms of its link to union renewal, organisation and appealing to union members; and may also enable achievement of economic and social outcomes through the national learning and skills policy arena.

However, there is also a need to be cautious when assessing the value that union learning is adding to the national skills scene and about what it contributes to the strength, influence and credibility of the trade union movement; and the previous sections of this article suggest that there are many challenges facing those working as practitioners and researchers in the field. In particular, it would seem from the evidence collated here, 
that union learning enhances skills-based learning and that the link with traditional liberal education is at risk of being lost.

As a way forward, it is apparent that education needs to be at the heart of resolving these issues so that, in developing union learning activities, there is a necessity to reinforce good practices derived from union education into the way in which union learning is delivered, in terms of building on the collective nature and social settings of the learning pedagogies. In turn it should also be possible to build on the advantages of union learning initiatives that new funding streams have enabled, particularly access to increased numbers of learners. Further, it will be necessary for those involved to be active and critical learners themselves, in order to challenge norms and make changes. This applies particularly to ULRs and others involved in learning policy in the trade union movement.

The voice from such learning will need to be exercised through the democratic processes of the union movement, which should in turn strengthen definition of the role of union learning. In this regard, Stirling (2007) argues that the challenge for the trade union movement is to realise the potential for union education to be a central means by which members shape union responses and directions, enabling debate about directions and unity across the movement and that trade union learning itself should be the subject of debate within trade union education programmes. Education/learning courses should enable ULRs and other union representatives and members to understand and debate the advantages, disadvantages and strategies towards union involvement in learning activities themselves. Such initiatives could act as a means of bringing learning centre stage in the union movement, enable further development of distinctiveness of content and delivery, 
and further development of practical methods for ensuring sustainability of this distinctiveness. Skilful, enthusiastic and imaginative union learning activists can build strong power bases. The power of agency, of individual's abilities to change their circumstances through learning, should not be underestimated.

\section{References}

Ainley, P. (1999), Learning Policy. Towards the Certified Society. (London: Macmillan). Calveley, M. (2007a), 'An historical overview of trade union involvement in education and learning in the UK', in Shelley, S. and Calveley, M. (Eds), Learning with Trade Unions. A contemporary agenda in employment relations. (Aldershot: Ashgate).

Calveley, M. (2007b), 'Trade union learning in the international context', in Shelley, S. and Calveley, M. (Eds), Learning with Trade Unions. A contemporary agenda in employment relations. (Aldershot: Ashgate).

CIPD (2004), Trade Union Learning Representatives: The Change Agenda. (London: Chartered Institute of Personnel and Development).

DfEE - Department for Education and Employment (1998), The Learning Age: a Renaissance for a New Britain. (London: HMSO).

DfEE - Department for Education and Employment (2001), Regulatory Impact Assessment for Providing Statutory Backing for Union Learning Representatives. (London: HMSO). 
Elsey, B. (1986), Social Theory Perspectives on Adult Education. Nottingham studies in the theory and practice of the education of adults. (Nottingham: Department of Adult Education, University of Nottingham).

Forrester, K. (2007), 'Becoming visible? Notes on work, union learning and education', in Shelley, S. and Calveley, M. (Eds), Learning with Trade Unions. A contemporary agenda in employment relations. (Aldershot: Ashgate).

Freire, P. (1972), Pedagogy of the Oppressed. (Harmondsworth: Penguin).

Grugulis, I. (2003), 'The contribution of National Vocational Qualifications to the growth of skills in the UK', British Journal of Industrial Relations, 41, 3, 457-475.

Healey, J. and Engel, N. (2003), Learning to Organise. (London, Congress House: TUC).

Holmes, L. (2004), 'Challenging the learning turn in education and training', Journal of European Industrial Training, 28: 8/9, 625-638.

Keep, E. and Mayhew, K. (1999), 'The assessment: knowledge, skills and competitiveness', Oxford Review of Economic Policy, 15, 1, 1-15.

Kelly, J. (1998), Rethinking Industrial Relations: Mobilization, Collectivism and Long Waves. (London: Routledge).

Kirton, G. (2007), 'The longer-term influence of women-only trade union schools', in Shelley, S. and Calveley, M. (Eds), Learning with Trade Unions. A contemporary agenda in employment relations. (Aldershot: Ashgate).

Leitch (2006), Prosperity for All in the Global Economy - World Class Skills. The Leitch Review of Skills. (London: TSO).

Lloyd, C. and Payne, J. (2002), 'Developing a political economy of skill', Journal of Education and Work, 15, 4, 365-390. 
Lloyd, C. and Payne, J. (2007), 'Tackling the UK skills problem: Can unions make a difference?', in Shelley, S. and Calveley, M. (Eds), Learning with Trade Unions. A contemporary agenda in employment relations. (Aldershot: Ashgate).

McBride, A. and Mustchin, S. (2007), 'A beneficial combination? Learning opportunities from union involvement in career and pay progression', in Shelley, S. and Calveley, M. (Eds), Learning with Trade Unions. A contemporary agenda in employment relations. (Aldershot: Ashgate).

Moore, S. and Wood, H. (2005), The Union Learning Experience: National Surveys of Union Officers and ULRs. (London: Working Lives Research Institute).

Moore, S. and Wood, H. (2007), Union Learning, Union Recruitment and Organising. Unionlearn Research Paper 1. (London: Unionlearn).

Rainbird, H. (Ed). (2000), Training in the Workplace. (Basingstoke: Macmillan).

Rees, L. (2007), 'New developments in union learning', in Shelley, S. and Calveley, M. (Eds), Learning with Trade Unions. A contemporary agenda in employment relations. (Aldershot: Ashgate).

Salaman, M. (2000), Industrial Relations. Theory and Practice, $4^{\text {th }}$ Edition. (Harlow: Financial Times Prentice Hall).

Shelley, S. (2007a), 'The outcomes and usefulness of union learning', in Shelley, S. and Calveley, M. (Eds), Learning with Trade Unions. A contemporary agenda in employment relations. (Aldershot: Ashgate).

Shelley, S. (2007b), 'Multiple partnerships in trade union learning', in Shelley, S. and Calveley, M. (Eds), Learning with Trade Unions. A contemporary agenda in employment relations. (Aldershot: Ashgate). 
Shelley, S. and Calveley, M. (Eds) (2007), Learning with Trade Unions. A contemporary agenda in employment relations. (Aldershot: Ashgate).

Spencer, B. (Ed) (2002), Unions and Learning in a Global Economy. International and comparative perspectives. (Toronto: Thompson Educational Publishing).

Stirling, J. (2005), 'There's a new world somewhere: The rediscovery of trade unionism', Capital and Class, 87, 43-64.

Stirling, J. (2007), 'Globalisation and trade union education', in Shelley, S. and Calveley, M. (Eds), Learning with Trade Unions. A contemporary agenda in employment relations. (Aldershot: Ashgate).

Stuart, M. and Wallis, E. (2007), 'Integrating learning into workplace bargaining: case studies of evolving trade union learning agreements', in Shelley, S. and Calveley, M. (Eds), Learning with Trade Unions. A contemporary agenda in employment relations. (Aldershot: Ashgate).

Sutherland, J. and Rainbird, H. (2000), 'Unions and workplace learning: conflict or cooperation with the employer?', in Rainbird, H. (Ed). Training in the Workplace. (Basingstoke: Macmillan).

Taylor, P. (1993), The texts of Paulo Freire. (Buckingham: Open University Press).

Thompson, P., Warhurst, C. and Findlay, P. (2007), Organising to Learn and Learning to Organise. Unionlearn Research Paper 2. (London: Unionlearn).

TUC - Trades Union Congress (2002), The Quiet Revolution. The Rise of the Union Learning Representative in the East of England. (London: TUC).

TUC - Trades Union Congress (2005), Skills White Paper: TUC response to Skills White Paper. (London: TUC). 
Wray, D. (2007), 'Have laptop, will travel: case studies in union learning', in Shelley, S. and Calveley, M. (Eds), Learning with Trade Unions. A contemporary agenda in employment relations. (Aldershot: Ashgate). 